\title{
JAHANGIR'S WINE CUPS: A STUDY OF THE ARTISTIC STYLES AND SYMBOLISM
}

\author{
Thabet, $\mathrm{H}$. \\ Islamic dept., Faculty of Archaeology, Fayoum Univ., Fayoum, Egypt \\ E-mail: htm00@fayoum.edu.eg
}

\begin{abstract}
The applied arts, e.g. cups of wine and opium, at the time of Indian Mughal emperors show how great their civilization and creativity were. The present paper is an artistic study of these cups, their styles at the time of Jahangir and their appropriateness to the function. It also investigates the materials used in manufacturing, decorations and the relationship between these decorations and the cups' functions. Additionally, it aims to study the philosophy of the Mughal emperors in drinking wine, how fond they were of these drinks despite the teachings of Islam and the development of drinking wine at the time of Jahangir that the depiction of the emperor holding a cup was a well-known phenomenon. Finally, it examines the coins minted during Jahangir's era and the symbolism of wine cups and their relations to him in some kingly scenes.
\end{abstract}

Keywords: Cup, Wine, Opium, Drinking, Mughal, Jahangir, Coins, Manuscripts, Paintings Bukhara,

\section{Introduction}

Drinking wine was an important aspect of the Mughal-Indian era that it was clearly depicted in some Indian manuscripts. For example, the era of Jahangir showed how fond he was fond of wine and opium. He was often depicted holding a cup in different scenes, whether manu- scripts or coins minted at that time. In addition, different materials were used in their manufacturing to faithfully express the development of applied arts in the era of Mughal emperors in India, in general, and that of Jahangir, in particular.

\section{The Philosophy of Mughal's Interest in Wine Cups}

\subsection{Before Jahangir}

Over the different Islamic eras, the scenes of drinking wines and the various tools and applied artifacts used for this purpose were known. For example, princes were depicted in wine circles. Therefore, wine scenes were executed in Fresco on the Abbasid palaces, the Mamluk metal artifacts in Egypt and Syria (1250-1517), the manuscripts of Mughal Ilkhanate
(1265-1335), the Persian painting at the time of the Timurid rulers (1387/1502) and Safavid rulers (1502/1737) depicting wine scenes in courts and picnic times that reflect the culture of the age [1]. In the Mughal era, although drinking wine was prohibited by Islam, this culture disseminated that it became an integral part of the Mughal court ${ }^{(a)}$ [2]. Many poets 
of the Persian literature handled wine, its drinking and symbolism. Additionally, some poems of the Persian literature discussed the various kinds of wine, they were known as alkhamiria [1]. For example, in Punjab as well as other Indian provinces, many poets discussed wine and dedicated full poems to it [3]. At that time, the Sufi thought greatly flourished affecting drinking wine. It represented various religious rituals, not only drinking. Many historians reported the spread of Mysticism in India that played a great role in the dissemination of such customs in the Mughal court, as reported by Jahangir in his memories [4]. The cups used were not only to drink wine but they had a certain symbolism. While the cup represented the world, the wine was the elixir of life [5]. At that time, Sufi poems discussed drinking wine as a form of spiritual pleasure that brought them closer to Allah. Although wine is prohibited in Islam, Allah promised believers that they will enjoy pure wine that will not make them drunk or sick and it has good flavor [6]. To the Sufi as well as others, wine symbolizes paradise. For example, Sufi poetry reports it as $k a$ 's al-mafabba (the loving cup) [1]. Abd Elnabi Fakhr Alzamani was one of the most important poets; he visited India in 1017 and joined the court of Jahangir [7]. Generally, wine spread in India in the Mughal era because it was advisable to drink wine in cold weather [8]. Drinking wine also spread in the Mughal court before

\subsection{Jahangir (1014-1037 H./1605-162}

Jahangir succeeded his father and was entitled Badshah-Alal-Ghazi [14]. He was the first Mughal ruler to has the title of (Djahngir) or (World-seizer); the king of the world. Therefore, he is depicted standing on the earth and the sun behind the throne [15]. He was fond of grandeur and splendor that his procession was incredibly magnificent with 10,0000 horsemen, more than 250,000 animals, about 500,000 persons, and a large number of elephants and predators. It extended to 1.5 miles [4]. Although Islam prohibited drinking wine, Jahangir drank a lot of it [4]. He also liked Sufism,
Jahangir. For example, Babur (1526-1530) was fond of wine and was described as the great drunk. He used to celebrate victory in parties where wine was drunk extensively. Furthermore, he used to drink before fighting wars [9]. He also had a set of wine cups made of precious metals, including gold and silver, but they were destroyed in his lifetime [10]. Humayun (1530-1539) and (1555-1556) was an addict of opium as mentioned in his memoir [4]. Instead of torturing enemies, He used wine for investigations. For example, after seizing Champanir, Humanyun knew that Bahadir Shah was hiding a treasure. Thus, he ordered his soldiers to make Bahadir Shah drunk instead of torture to know the place of treasure [9]. Abu Elfadl, the minister, reported that Akbar (1556-1605) was an addict of opium and alcoholic [11]. By nature, Akbar was a Sufi and loved meditation [11]. He was known to be alcoholic from his $18^{\text {th }}$ that he used to drink more than 20 cups a day. Roe reported that the smell of wine emitted from Akbar's court [10]. At his time, the senior statesmen drank wine, especially on certain occasions and hunting trips [12] and he also drank with them [13]. The new legislation that he issued included an article that permitted wine drinking as it supports the body according to the physicians' recommendations. He also allowed establishing a shop, near the palace, to sell wine that he regulated work there and fixed wine prices [9].

\section{and his interest in drinking wine}

mysticism and Alborhamia doctrine [15]. He was alcoholic from the age of $18^{\text {th }}$. At the age of 46, he became an opium addict. However, he deeply regretted the time spent in drinking alcohol or opium addiction [16]. On drinking wine, he was sobered down although, he was sobered up in other times [17]. Later, his hands trembled that he was not able to drink wine, but with the help of another person [18]. He had a famous motto that "I wanted only a bottle of wine and a piece of meat to keep myself merry" [19]. His great love for wine might be attributed to the fact that he was brought up and 
educated by Shiekh Saleem in Sakarya near Agra and Jahangir was named after him. Jahangir was brought up in an environment of Sufism. Sufis used to

\section{Types of Wine in India}

In ancient times, many types of wine were known, that were mentioned by historians and poets, such as Elbatchreck that was made of fermented grapes to which sugar was added. Many scholars reported that India had known white and grape vines that were used to make wine [22]. Tastes were carefully graded. For example, quince and pomegranate provided the best relish with wine [8]. Other strong types of wine were also known, including those made of grapes drink wine [20] as they believed that it was a great motif to faith and it has a special symbolism [21].

and sugar cane [19]. Additionally, Ubayd Allah ibn Yahya, the minister of Caliph al-Mutawakkil (205-247A.H/ 822-861A.D) reported that when he visited India, they offered him coconut wine [20]. Then, he gave the king grape wine. Opium was one of the most important plants that emperors addicted to. India was famous for planting opium and was its second most important export after grains to the West. It was grown in the valleys of Ganges, Punjab and Rajput [23].

\section{Artistic Styles of Jahangir's Wine Cups}

Mughal emperors were fond of wine cups and Jahangir was the greatest. Some historical resources reported that he possessed 50 of them [1]. At his time, they took many models: I) Bowl model that takes the form of a bowl. The base was flat with no handle to hold them, but they were gripped from the body itself, as if the person is holding a half bowl used to drink wine in the different Islamic ages, including a cup of dark green jade and gilded from outside. It was $2.6 \mathrm{~cm}$ high and $4.9 \mathrm{~cm}$ wide. The body as decorated with various geometric decorations, taking the form of vertical curves that divided the body into rectangular parts that were decorated with "Jahangir padshaha ibn Akbar" (i.e. The King Jahangir son of Akbar). Every word was in a part and replicated, fig. (1). Another cup that dates back to the age of Jahangir was made of green jade. It was $7.3 \mathrm{~cm}$ high and $12.2 \mathrm{~cm}$ wide. On the body, a set of floral decorations of lotus in high relief. At the top, there was a written bar of rectangular cartouches of Nasta $\square$ liq script. They were statements of the name of Jahangir ibn Akbar and Persian poetry to praise drinking wine as the drink of life [17]. These lines are translated as:
"This is the cup of water [of life], nourisher of the soul / Of King Jahangir [son of] King Akbar." On the lower part, the Hijri date (i.e. 1012; the $7^{\text {th }}$ year of Jahangir's reign) was written, fig. (2). Other forms were designed like a cup with a slightly high base and it had no handles. For example, a model was made of copper. It was $16.5 \mathrm{~cm}$ high and $34 \mathrm{~cm}$ wide in the National Gallery of Modern Art, Mumbai. A set of moldings decorated the body from outside. Each molding comprised different decorations. For example, the middle modeling comprised scenes of horsemen trying to hunt deer beside the scenes of elephants. They were implemented on a ground of floral decorations. Other modeling comprised Persian writings in Nasta $\square$ lì script on a ground of floral decorations of Persian poetry on wine. The whole cup seemed to be royal, fig. (3). Some scholars reported that this piece was probably made in Iran because its writings were quoted from the well-known sagi-nama poetry that was Shiite and was known among Safavids. Although Jahangir was Sunni, this cup was a belonging of Nour Jahan, his wife, who was Persian originally. Whatever the case may be, it was owned by Jahangir [17]. Another cup was 
attributed to Jahangir because of the writings on the body that was divided into rectangular areas. In the middle, there were Persian writings that contain the name of Jahangir, Persian poetry, and the date $1016 \mathrm{H}$. They stated "By command of his majesty, the great khaqan, lord of the kings of the world, manifesto of divine favors in the offices of Caliphate and kingdom, the sun in the firmament of the world sovereignty, the moon in the sky of justice and felicity, Abu al Muzaffar, son of king Akbar, nur ad-din Mahmoud Jahangir the emperor, Warrior of the Faith, the form of the cup attained completion in the year 1016". The upper part of the body contained writings in cartouches: "The wine of the cup/ of the emperor/ of the age/ second [regnal] year". At the bottom, the writings were: This cup body imbued with spirit - a jasmine leaf suffused with [purple] of the judas tree. Such statements indicated the use of this cup to drink wine. It was made of dark-colored jade. It was $5.5 \mathrm{~cm}$ high and $7.5 \mathrm{~cm}$ wide, fig. (4). II) The cup with handles that took two forms. The first form generally resembled a half bowl that was used to drink wine, while the other was made of precious stones. For example, a cup was made of green jade at Victoria and Albert Museum. It was $3.8 \mathrm{~cm}$ high and $8.8 \mathrm{~cm}$ wide. The body takes the form of a half bowl which is based on a slightly high base. The handle started at the top part of the body and ended in the middle. Additionally, the top part of the body was decorated with rectangular cartouches including writings in nasta'liq script stating that: "Through the World-Conquering Shah, the world found order/ Our time became filled with light by the radiance of his justice/From the reflection of his spinel-colored wine may/ The jade cup be forever like a ruby". The rectangular cartouches were separated by other cartouches that contained the year of manufacture, i.e. $1022 / 1023 \mathrm{H}, 8^{\text {th }}$ regional year, and the name Sa'ida-ye Gilani who was the head of the manufacturer section at the time of Jahangir and was specialized in adding the precious stones and jade to the artifacts. Conseq- uently, he was the manufacturer of the cup that was made of jade, fig. (5). The second type was carved in the form of the leaves of the plant in the form of poppy leaves. The handle was shaped like a branch that wrapped up the body from the bottom and ended with a large leaf. The body contained the name Jahangir and the year 1017. It was kept in a private collection, fig. (6). III) Half pumpkin model: Its bases were made in the form of foliage with overlapping leaves, shaped like a closed tulip that was known at that time [5]. For example, a cup kept at the Asian Art Museum, San Francisco, California had a body like a half pumpkin and a small and slightly high base. Its handle was a part of the body. The cup was held from both the body and the handle. It also included writings in Persian writings in nasta'liq script stating, "Drink at the command of God", indicating its use to drink wine. It also took the half pumpkin form that was the most common form at the time. It may be dated back to the time of Jahangir, although there is a similar artifact with his name and kept at the British Museum for many reasons. The time of Jahangir witnessed the spread of the manufacturing of wine cups and most of the other pieces date back to Jahangir. This artifact contained Persian writings similar to those on the other cups of Jahangir. It was made of jade that was the most widely used material at his time. Jahangir owned 50 cups of jade. Additionally, there were Persian writings in nasta'liq script. The name of Shah Jahan was engraved on the artifact, fig. (7). It is noticed that these styles were greatly influenced by the half of the pumpkin that was used in different times in drinking wine. These pumpkins kept their sugar taste for a long time. Using them to drink wine added a good taste to the wine. This caused the spread of the different kinds of pumpkins to long periods in drinking wine. The Indian artists were affected by these forms. Therefore, different forms of cups appeared, especially the half pumpkin that was used to drink wine. 


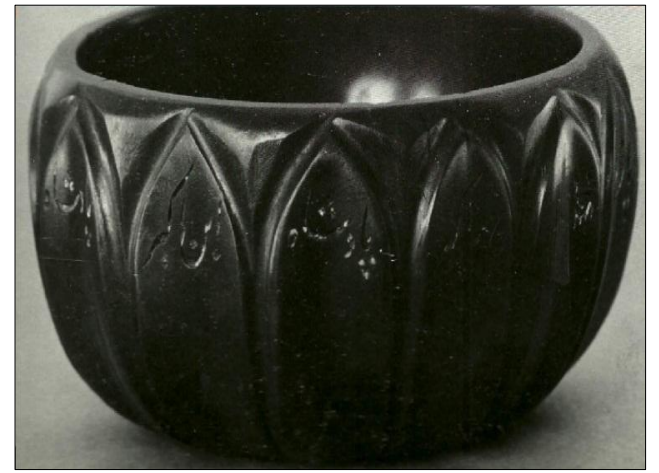

Figure (1) Shows wine cup of dark green jade, Jahangir 1605-1628, Brooklyn Museum. Stuart Cary Welch: India Art and Culture, pl. 124

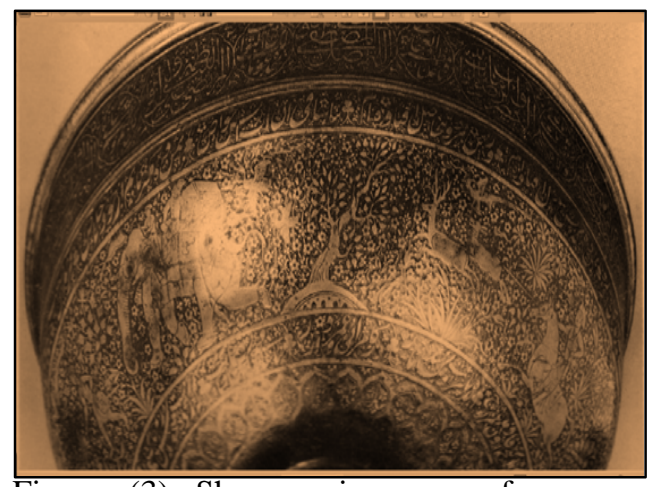

Figure (3) Shows wine cup of copper, Jahangir 1605-1628, Museum of art, Bombay in Waste India, Stuart Cary: India Art and pl. 119

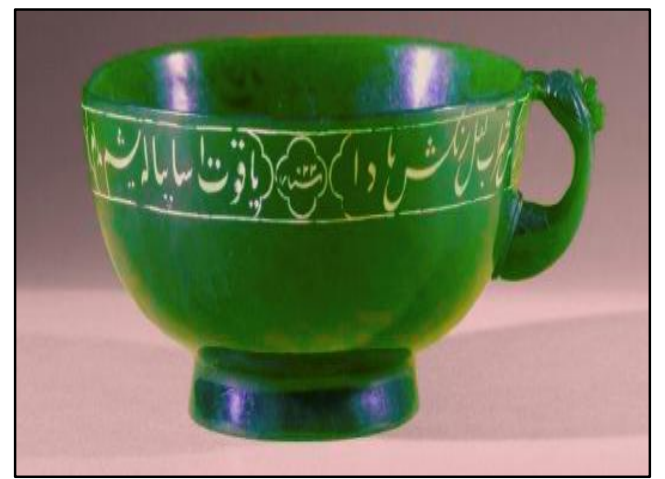

Figure (5) Shows wine cup of dark green jade, Jahangir1 605-1628, Victoria and Albert Museum

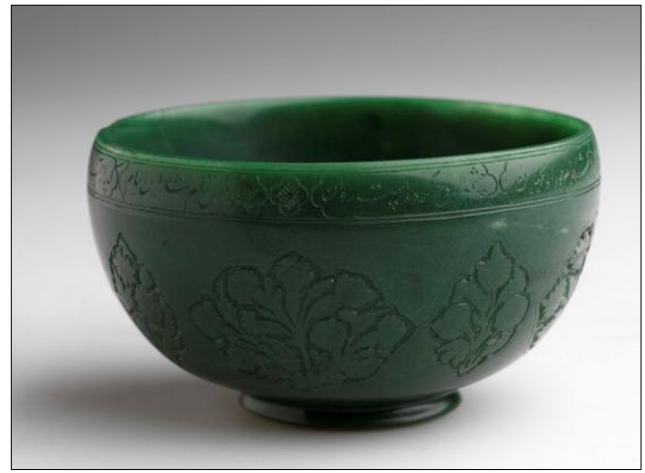

Figure (2) Shows wine cup of dark green jade, Jahangir 1605-1628, Museum of art, Rohde Island School of Design

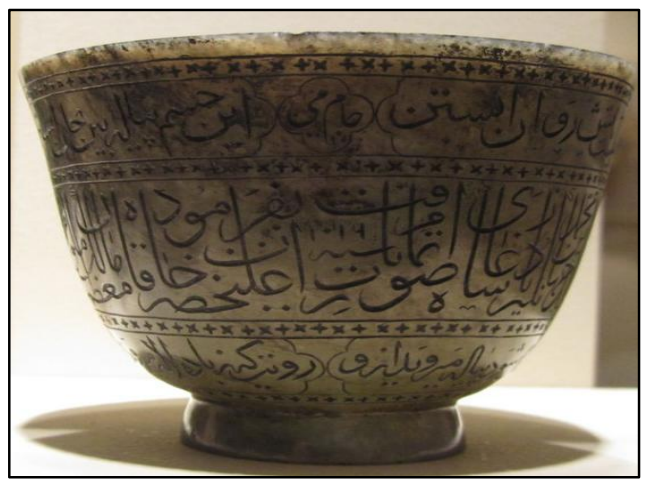

Figure (4) Shows wine cup of jade, Jahangir 1605-1628, Brooklyn Museum.

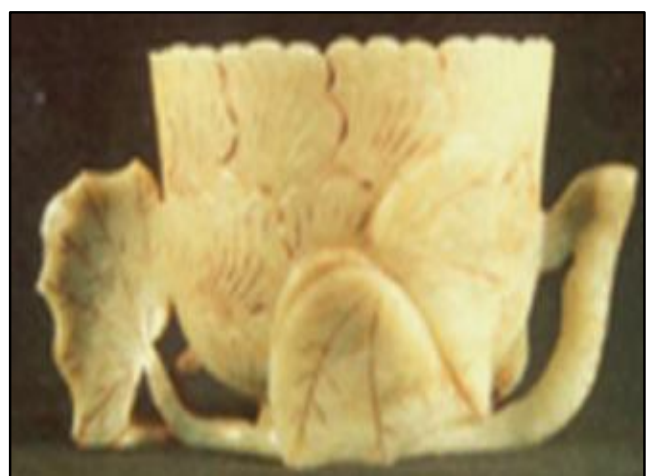

Figure (6) Shows wine cup of jade, Jahangir 1605-1628, collection of Bharat Kala Bhavan. - Stuart Cary Welch: India Art and Culture, pl. 124

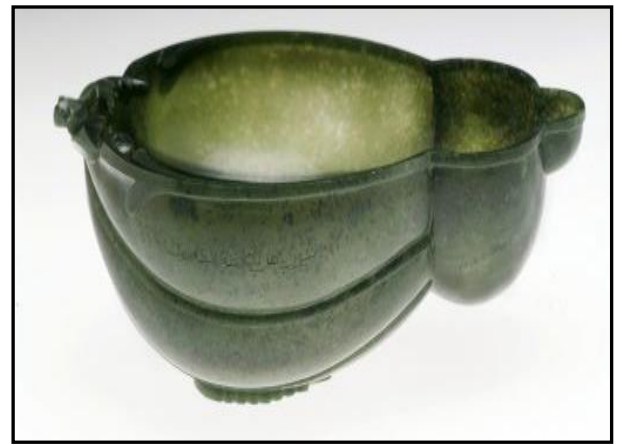

Figure (7) Shows wine cup of green jade, Jahangir 1605-1628, Asian Art Museum, California 


\section{Dimensions of The Cups and Their Functionality}

The cups used to drink wine were of small sizes, not higher than $17 \mathrm{~cm}$. Sometimes, they were smaller; about 2.6 $\mathrm{cm}$ high. Regarding the opening, they were 4.9 to $35 \mathrm{~cm}$ wide. Usually, their height was less than the width. As a result, they were of small sizes to fulfill a specific function, namely drinking wine. Naturally, they were small as the wine was not drunk in big cups because of their severe impact on the human being and the high value of its substances, whether wine or opium. Additionally, they were made of precious stones that were of high value and rare, fig. (8). Regarding the parts of the cup, the body

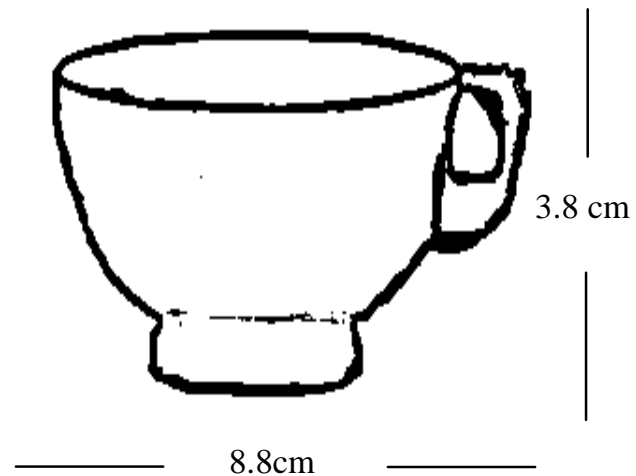

Figure (8) Shows dimensions of the cups.

\section{Materials Used}

Precious stones were one of the most widely used materials in manufacturing the wine cup of Jahangir. The Mughal rulers in India were interested in precious stones, which were imported from Kabul. They used them in a different form of applied arts, especially in the arts in the palaces of kings or noblemen [23]. They had a high ability to convert precious stones, e.g. corundum and jade, into highquality artifacts. Wine cups were one of the art forms used for the emperors as they were of the personal belongings of the emperor. Some Persian sources report that Jahangir was interested in precious stones, especially jade, that was used in creating many artifacts, including wine cups. Some sources reported that Jahangir had 500 wine cups of jade [24]. In his was the main part and was covered with various decorations. In these cups, the body was largely affected in the half pumpkin that was formerly used in drinking wine. As for the handles, some cups did not have a handle so they were held from the body itself due to their small sizes accordingly; they fulfilled the required function of the first model. The second model contained a handle that began at the top and ended in the middle. It helped the person to hold the cup. In the third model, the handle was part of the body. Thus, the cup was totally held, not only the handle due to the small size of the cup.

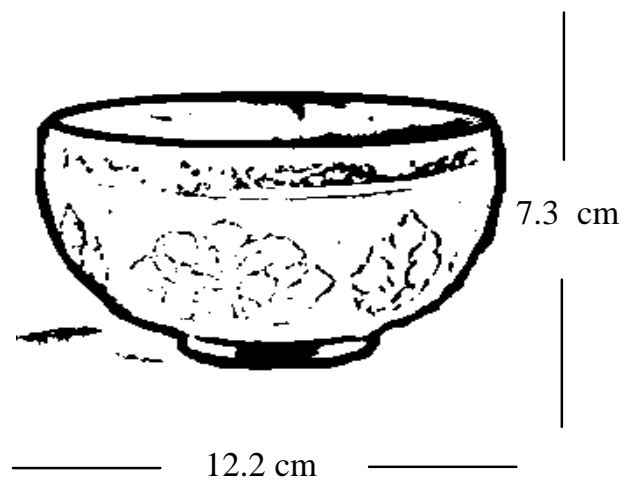

memoir, Jahangir mentioned that he had wine cups of eshime (yashm) and he was interested in importing the manufacturers of such stones from outside India, showing the difficulty of manufacturing these cups from jade [25] as they required a high effort, skill and difficulty and that the Mughal artists were skillful in this industry. Additionally, there were various forms of multicolor jade in the manufacturing of wine cups such as the green jade in fig. (1, $2,5 \& 7)$ and the dark jade, fig. (4\& 6). During the reign of the Mughal emperors in India, various materials were used to make wine cups. Vessels were made from metals, especially copper and bronze [26]. Copper has been known in India for ages. Many sources mentioned the importance of copper in India and the quality of products that were produced in India from 
copper and bronze. For example, Elpones reported the quality of copper in India and that Indians used copper coins [27]. The Mughal emperors in India were famous for the production of the artifacts from copper, bronze and various metals. The artifacts produced by the royal workshops were intended for use in the royal palaces and the palaces of the nobles and the senior statesmen [28]. Cups were covered with enamel and they were polished and refined in order not to be mixed with wine [16]. For example, a cup of copper that dated back to the time of Jahangir was coated with enamel fig. (3)

\section{Cups' Decorations and Their Relation to the Function \\ 7.1. Written engravings}

Written decorations were of the most important decorations on these cups. Artists applied the high relief writings to the applied artifacts, while low relief writings [29]. Such inscription was executed on the body in both low and high relief, figs. (1, $2 \& 4)$. They played an important role in the decoration of cups at that time and were mostly made of the metal artifacts from outside due to their function. They took the forms of cartouches or decorative bands. Persian writings were in nasta'liq script and they had different contents. A) In praise of wine Some Persian poetry that appeared on the Indian metal artifacts [30]. Such writings, known as sagi-nama, sometimes appeared at the top of the cooper wine cup's body, fig. (3). Other writings were on the body of the cup that was made of dark jade. They were in praise of wine and describing it as the food of the soul, fig. (4). On another cup, the writings stated: "drink at the command of God", fig. (7). It is noted that these writings were directly related to the function of the cup that was intended to drink wine or opium. Therefore, these phrases encourage drinkers to drink these wines and remember them of its benefits. B) In praise of Jahangir some writings also included the name of Jahangir and praised him. For example, on the body of a jade cup,

\subsection{Floral ornaments}

They were engraved on the surface of the metal; it is the tradition of the decorations of the Indian Mughal metals [31]. On the wine cups, many floral ornaments, including lotus and that was one of the most important ornaments on architecture and applied arts at that time. a statement with the name Jahangir and son of Akbar was engraved, fig. (1). On other writings, poetry praised Jahangir and his morals and mentioned his title a master of the world, fig. (3), while other statements praised his justice, fig. (5). Such writings were directly related to the function of the cup; praising Jahangir. Sometimes, they mentioned the benefits of drinking wine and its impact on Jahangir that he always maintained justice. C) Chronological writings These writings mentioned the date of manufacturing the cup such as 1012 H., fig. (2) and 1016 H., fig. (3). Sometimes, they contained more than one date such as the date of manufacture and the date of the year of Jahangir's reign. For example, on a cup (fig. 5), the date of manufacture, i.e. $1022 / 1023 \mathrm{H}$. and year 8 of Jahangir's reign were engraved. These inscriptions are useful in dating back the artifact, but they have nothing to do with its function. D) Names of the manufacturers Sa'idaye Gilani, the head of manufacturers at the time of Jahangir, were engraved on a wine cup. He was also specialized in adding precious stones and jade to the artifacts. Thus, he might be the manufacturer of the cup that was made of jade, fig. (5) such phrases have no relation to the cup's function.

It appeared as an Iranian influence. It was engraved in large size and was duplicated on the whole body, representing the main theme in the decoration of the cup, fig. (2). Arabesque was another form of floral ornaments. It comprised engraved decorative elements half of palmette that overlap 
in a coordinated geometrical manner. Additionally, full palmettes and other types of flowers and fruits may emerge Arabesque was carried out as a background to some scenes on the body of the copper cup in addition to the tree drawings that penetrated the scene, fig. (3). These ornaments were not related to the cup's function, fig. (9).

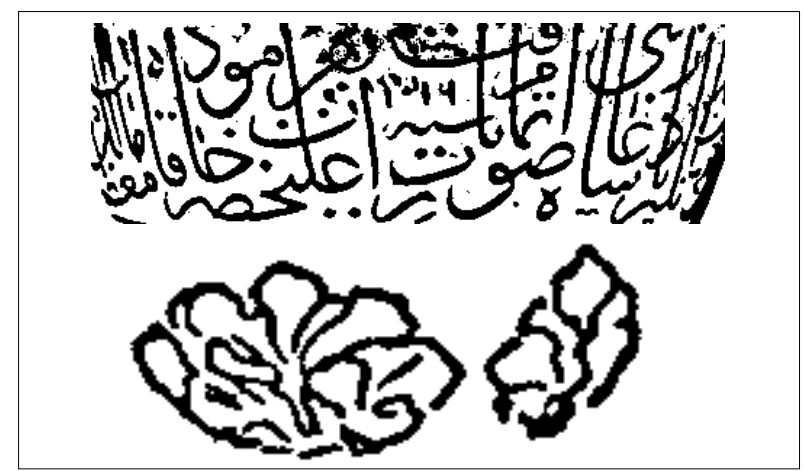

Figure (9) Shows written and floral ornaments decorative in wine cups

\subsection{Pictorial scenes}

A hunting scene and another of the elephants were drawn on a cup of wine, fig. (3). These drawings depicted horsemen chasing animals on a floor of floral ornaments. They were known to the Indian Mogul arts, in general, and were depicted on wine cups. These scenes were important as they highlighted a favorite hobby for Jahangir that he did in his free time and was keen to register because it was part of his personal history and an attempt to commemorate him. Elephant scenes were one of the most important decorative elements that appeared on the applied arts in the Mughal Indian era. Elephants were closely related to India. Their depiction was a significant scene in the Mughal arts as they showed the greatness of the Imperial Court. These scenes were also indirectly related to the function of the cup. In his memoir, Jahangir claimed that he preferred drinking wine on the hunting trips. Because elephants were part of the hunting trips, Jahangir used them in his own parade and they were part of the pictorial scene, fig. (10).

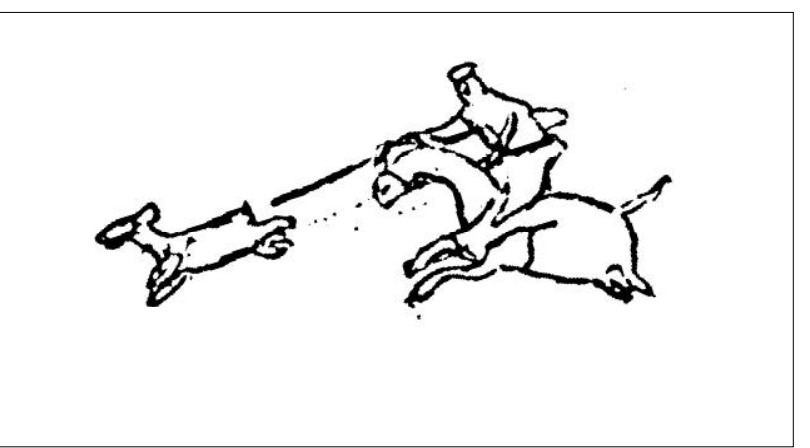

Figure (10) Shows pictorial scenes decorative in wine cups.

\section{Discussion}

\subsection{Wine cups in painting and architecture}

The Mughal Indian painting derived its artistic elements from the Persian one. It achieved great progress during the reign Jahangir who was particularly interested in it [32]. For example, scenes of wine drinking scenes in the court were painted. Additionally, the wine was served with the meal and was sometimes painted with music. A portrait, kept at the Walters Art Museum, Baltimore, USA, showed Jahangir offering a wine cup to a young woman, which was a habit in the Mughal Indian painting. At that time, women appeared in drinking wine scenes with 
men [32], fig. (11-a \& b). In Jahangir's era, more interest was paid to portraits. Often, the emperor drew himself either alone or in his court and he was imitated by the noblemen. Many portrayers were widely publicized, including Bashandas, Manuhr, Abu Hassan and Jafredhan. In these portraits, Jahangir was depicted olding wine cups, fig. (11-c). In others, he app-eared taking the royal sitting inside his own balcony and holding a wine cup, fig. (11-d). In these portraits, wine cups were similar to those Styles attributed to Jahangir. They were small and of the same models. Although there were no samples of wine cups dating back to Jahangir's reign that were made of glass, a portrait depicted him holding a cup of translucent blue glass that seemed to be imported from Europe. Similar forms of wine cups were also depicted [33], fig. (11-e). Despite a large number of paintings showing Jahangir holding a wine cup, whether portraits or pictorial scenes, he was never depicted drunk as a result of the tradition of royal painting during the reign of
Mughal Indian emperors; this status was not desirable [1], fig. (11-f). Jahangir was fond of wine that this passion was reflected on his architectural establishments. For example, his palace in Agra in Uttar Pradesh, was decorated with precious stones mosaics, and with drinking paintings [4]. In the mausoleum of E'temad eldawla in Agra (1031/1622), a corridor was covered with marble fillings and decorations of grape leaves, flowers, vases and wine cups [34], fig. (11f). It might seem natural to record pictorial scenes of wine drinking on the walls of Jahangir's palace. It was a place where drinking parties were likely to be held. However, it was unnatural to draw wine cups on a mausoleum. Perhaps, these decorations were inspired by the verses of the Holy Qur'an that promised the faithful to drink wine in Paradise, especially as they were depicted with the vases and flowers, indicating that these cups had unusual symbolism and indications for drinking wine at the time.
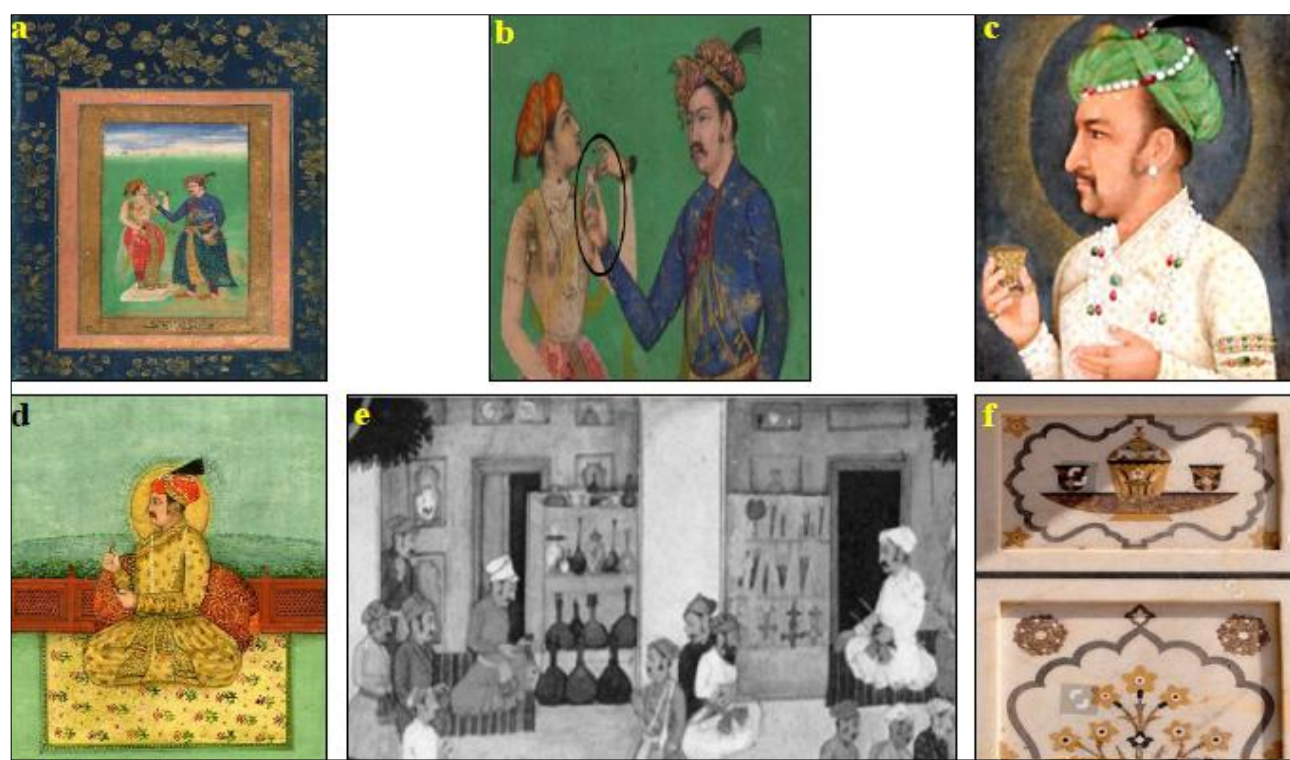

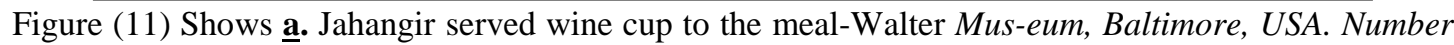
Reserved: MS.W668.fol. $40 \mathrm{~b}$, $\underline{\mathbf{b}}$. wine cup in before image, $\underline{\mathbf{c}}$. Jahangir hold wine cup, $\underline{\mathbf{d}}$.

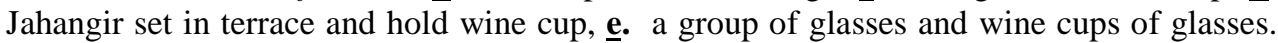
Digby. S., (1973), a corpus of 'Mughal' Glass, Bulletin of the School of Oriental and African Studies, Vol. 36, No. 1, pl.3. f. wine cup in the mausoleum of E'temad eldawla in Agra.

\subsection{Wine cups on coins}

The wine cup became one of Jahangir's personal possessions as well as an official feature of the ruling system.
Therefore, Jahangir coined some coins on which he was depicted holding a wine cup [15]. This affirms their importance as 
they were manifestations of legitimacy. Jahangir's paintings appeared on the golden and silver commemorative coins, including half-drawings of his portraits while he was holding a wine cup known as the "Bacchanalian Coin" [35]. On the obverse, Jahangir was on his balcony with his left hand on it, while holding a cup of wine in his right hand and the face was surrounded by a halo. On both sides, there were Persian inscriptions in Nastaliq script of the reginal year, fig. (12-a). Another golden coin contained four horizontal lines of the name and surname of Emperor Jahangir and the name and surname of his father, Emperor Akbar. While the third line ended with the Hijri calendar, the last line contained the reginal year, i.e. year 7 . On the obverse, the emperor was depicted while lifting the cup with the left hand to his mouth [36], fig. (12-b). On a third coin, a portrait of Jahangir seated on the throne, standing next to the balcony and holding a cup in his hand, fig. (12-c). Regarding the balcony, Jahangir was keen on disseminating ultimate justice by observing the complaints of his people. In his memoir, he said: "After being crowned, the first thing I ordered was to extend the chain of justice to know, myself, the grievances of the oppressed." He stood at his balcony to be directly connected to people [37]. He also mentioned that: "I have worked since the first day I went down in Ahmedabad to sit after noon prayer at the balcony for one or two hours there will be no door between me and the people, nor a wall, nor a guard. Despite being tired, I've never stopped of doing so" [18]. He was depicted holding a cup of wine, which confirms that drinking wine was a legal ceremony. He was depicted the same way on coins and paintings while observing the complaints of people holding the cup to show his sovereignty and prove his legitimate Judgment, fig. (12-d). Thus, Jahangir's wine cups transcended the stage of mystical expression and symbolism of Sufism, but they reflected the political ideology and legitimacy of the rulers. This caused the existence of cups of rulers of their personal belongings. At the time of Jahangir, wine cups became a manifestation of the legitimacy of the ruler as well as manifestations of community participation of the ruler and the people. He liked to be surrounded by the symbols indicating his divine power and manifestations of his justice and control of the empire. Therefore, there were used as moral, social and literary propaganda [38]. In these portraits, he was depicted holding a wine cup which clearly indicated his legitimacy and sovereignty as one of his titles was the king of the world. As a result, he was shown in portraits and on coins, overlooking people from a balcony and holding a wine cup.
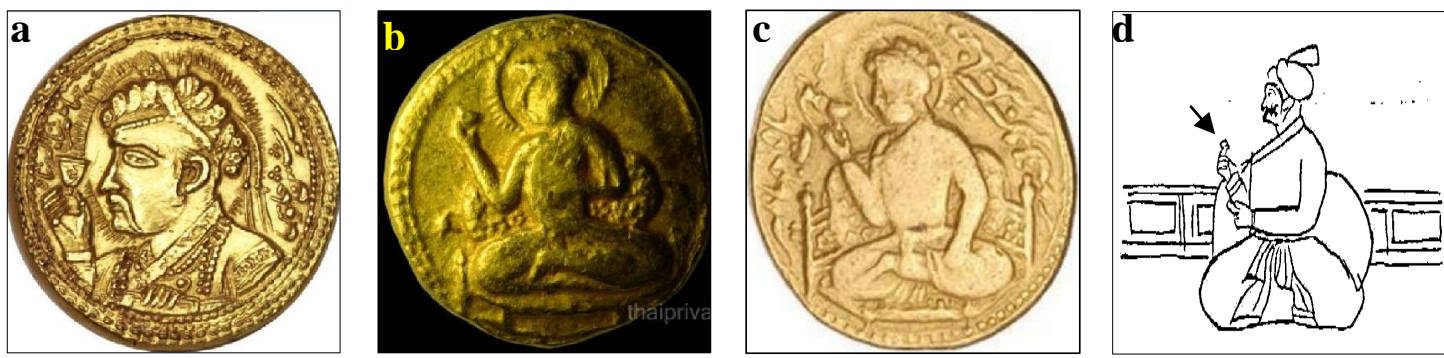

Figure (12) Shows a. Jahangir hold wine cup in golden coin, www.zeno.com.No.120991, b. Jahangir set in balcony and hold wine cup in golden coin. www.tha iprivatehand.com, c. Jahangir set in balcony and hold wine cup in golden coin, Parmeshwari Lal, Coins, pls, xxvii, 286., d. Jahangir set in balcony and hold wine cup in painting.

\section{Conclusions}

Through the previous study the following points could be * Generally, drinking wine was known in the Mughal era as a result of the flourishing of Sufi thought. Thus, drinking wine had certain symbolisms with Sufism that many poets in the Persian literature tackled wine and its various symbolisms. * Various kinds of wine were known in India, including grape and coconut. Therefore, drinking wine was familiar in the courts of Baber and Jahangir. Baber drank wine on many 
occasions and had special cups for this purpose that was made of valuable materials such as gold and silver. Humayun was also a wine addict. Furthermore, Akbar was a wine addict and enacted special legislations in his constitution that allowed the establishment of wine shops. At his time, drinking wine spread among his senior statesmen. * Jahangir was alcoholic since childhood because of being brought up by Sheikh Salim and being overwhelmed by Sufi ideas. Accordingly, he had a large number of wine cups. * At the time of Jahangir, wine cups took various forms. For example, the bowls form that were created like a semi-circle. The basis was designed in a flat shape and it did not contain handles to hold the cup, but they were held from the body. Another model was a cup with handles that took the half bowl form, while the other model was a cup engraved in the form of plant leaves, e.g. poppy leaves. The third model was a half-pumpkin cup that was used to drink wine. It was of a small size that did nor exceeded $17 \mathrm{~cm}$ high and $35 \mathrm{~cm}$ wide. * Precious stones were the most commonly used materials in the manufacture of wine cups, especially the dark green jade. Copper was also used in this industry. * The decorations on these cups varied during Jahangir's era. Some of them were directly related to the function of the artifact, including the poems that praised drinking wine. Other decorations did not have a direct relationship such as hunting scenes. Dating statements or floral ornaments were not related to the function of the cup. * Some manuscripts of Jahangir depicted him holding a cup of wine, whether in portraits or scenes of wine parties. They were similar to the Styles dating back to him that they were small and took the same forms. Jahangir was not depicted drunk that it was not desirable in the royal traditions. * Paintings of wine cups and drinking were depicted on the buildings in Jahangir's era, including his palace in Agra, Uttar Pradesh and the mausoleum of E'temad eldawla in Agra. * Various paintings on coins depicted Jahangir holding a cup of wine. They were similar to the pictorial scenes that depicted him holding a cup beside the window and overlooking people to consider their affairs. *At the time of Jahangir, wine cups exceeded the habit of being addicted by the rulers and Sufi implications to reflect the political ideology and legitimacy of the rulers. This made some cups of the rulers' personal belongings as well as a manifestation of community participation. Jahangir was depicted holding wine cups as a symbol of legitimacy and sovereignty. Thus, the cup symbolized the world, while wine was the elixir of life.

\section{Endnotes}

(a) India known wine from antiquity and Varuni was their goddess of wine.

\section{References}

[1] Khare, M., (2005). The wine-cup in Mughal court culture-from Hedonism to Kingship, The Medieval History Journal, Vol. 8 (1), pp: 143-188.

[2] Havell, E., (1911). The ideals of Indian art, E. P. Button \& Company, NY.

[3] Khan, P., (2013). The broken spell: The romance genre in late Mughal India, $\mathrm{PhD}$ dissertation, Faculty of Arts and Sciences, Columbia Univ.

[4] Balabanlilar, L., (2009). The emperor Jahangir and the pursuit of pleasure, Journal of the Royal Asiatic Society, Vol. 19 (2), pp: 173-186.

[5] Wilkinson, J., (1934). Shah Jahan's drinking vessel, The Burlington Magazine for Connoisseurs, Vol. 64. (373), pp: 186-187.

[6] Rustomji, N., (2003). The garden and the fire: Materials of heaven and hell in medieval Islamic culture, $\mathrm{PhD}$

dissertation, Faculty of Arts and Sciences, Columbia Univ.

[7] Marshall, D., (1967). Mughals in India: A bibliographical survey, Asia Pub. House, NY.

[8] O'Hanlon, R., (1999). Manliness and imperial service in Mughal north India, Brill, Leiden.

[9] Sharma, S., (1943). Mughal Empire in India (1526-1761), Part 1, Karnataka Painting Press, Bombay.

[10] Wilson, W., (1899). Rulers of India "Akbar and the rise of the Mughal empire", University of Oxford, UK.

[11] Anand, S., (2001). Predatory care: The imperial hunt in Mughal and British India, Journal of Historical Sociology, Vol. 14 (1), pp: 91:97.

[12] Elharawy, N., (1995). al-mūslìmūn fì al-hīnd mīn alfātīh al 'arābì ìla alaīst'amar al baīritani altargama 
alkamīlī taba'a akbārī (Muslims in India from the Arab conquest to the British colonization "Complete biography of Tabakat Akbari"), Part 2, General Egyptian Book Authority, Cairo.

[13] Divan, A., (1983). A pocket book for Akbar, The Hagop Kevorkian Fund, NY.

[14] Sajida. S., (1989). Religion and state during of Mughal emperor Jahangir (1605-1627), Studia Islamica, Vol. 69, pp: 95:119.

[15] Whitehead, R., (1929). The portrait medals and zodiacal coins of the emperor Jahangir, Journal of the Royal Numismatic Society, Vol. 9, pp: 1-25.

[16] Cary, S., (1900). India art and culture 1300-1900, The Metropolitan Museum of Art, NY.

[17] Jaffar, S., (2015). The Mughal Empire from Babur to Aurangzeb, S. Muhammad Sadiq Khan Printing, Lahore.

[18] Elnemer, A., (1990). Tārìkh al-islām $f i$ alhind (History of Islam in India), General Egyptian Book Authority, Cairo.

[19] Williams, J., (1906). The history of India, Vol. XI, The Grolier Society, London.

[20] Majed, A., (1986). Tārīkh al-hātara al-islāmiafì al-'oūsor al-ūsta (History of the Islamic culture in the Middle Ages), $5^{\text {th }}$ ed., Anglo, Cairo.

[21] Hijjaw, Q., (1990). A medieval Islamic book of gifts and treasures: Translation, annotation, and commentary on the (Kitab al-Hadayawa alTuhaf), PhD dissertation, Faculty of Arts and Sciences, Harvard Univ.

[22] Gustave, L., (2014), Hātarat al-hīnd (Civilizations of India), Arab World Print House, Cairo.

[23] Cary, S., Marilyn, J., Marie, L. \& Annemarie, S., (1979). Islamic art, notable acquisitions, Metropolitan Museum of Art, NY.

[24] Gray, B., (1966). The art of Mughal India: Painting and precious objects, Artibus Asian, Vol. 28 (1), pp: 99-101.
[25] Swarup, S., (1996). Mughal art: A study in handicraft, Came Kala Prakashan, Delhi.

[26] Watt, G., (1903). Indian art Delhi, The Superintendent of Government Printing, Delhi.

[27] Aga-Oglu, M., (1944). A brief note on Islamic terminology for bronze and brass, Journal of the American Oriental Society, Vol. 64 (4), pp: 223:231.

[28] Rogers. J., (1998). Gold, silver and bronze from Mughal India by Mark Zebrowski, The Burlington Magazine, Vol. 140 (1145), pp: 564-565.

[29] Elsedeq, M., (1987). Dìrasāt alnākoūsh al-'arābīafì al-daoūla almāqūlia wa atharoūha al-hātarī (Studies the Arab inscriptions in the Mughal Indian state and their cultural effect), $\mathrm{PhD}$ dissertation, Faculty of Sharia and Islamic Studies, Umm Al-Qura Univ.

[30] Dimand, M., (1982). Al-Funūn alIslamīyah (Islamic arts), Dār AlMaarif, Cairo.

[31] Michell, G., (2007). The majesty of Mughal decoration: The art and architecture of Islamic India, Thames \$ Hudson, London.

[32] Alvan, C., (1931), Mughal Painting, Parnassus, Vol. 3 (2), pp: 36-37.

[33] Digby, S., (1973). A corpus of 'Mughal' glass, Bulletin of the School of Oriental and African Studies, Vol. 36 (1), pp: 88-96.

[34] Michell. G., (2008). Indian Islamic architecture forms and typologies: Sites and monuments, Brill, Leiden.

[35] Hodivala, M., (1976). Historical studies in Mughal numismatics, The Prince of Wales Museum, Bombay.

[36] Elmarakby, R., (2014). Rūsūm alkaīnāt al-hāìya 'ala al-maskūkat fí alhīnd khilal al fätra mīn al-karn al'ashar ìla al-karn al-thalth ashr alhājrī dirassa mūkarna m'a madarst altasū̄r wa al-fūnūn al-mūasra (Figural organisms on the coins in India during the period from the tenth century $A H$ to the thirteenth century AH: A comparative study of Persian painting and 
arts), $\mathrm{PhD}$ dissertation, Archaeology and Civilization dept., Faculty of Arts, Helwan Univ.

[37] Ahmad, J., (2012). Al-Nūkūd abatārāt al-māqūl hāta nīhayiat 'ahat jahanjir dirassa atharīa fānia (The coins of Mughal emperors in India till the end of Jahangir's Reign: An artistic archaeological study), $\mathrm{PhD}$ dissertation, Islamic Archeology dept., Faculty of Arts, South Valley Univ.

[38] Okasha T., (2015). Fūnūn al-shārk alaūsat "alfānal-hīndi" (Arts of the Middle East "Indian Art"), Dar El-Shorouk, Cairo. 